\title{
PENGARUH KONSENTRASI HORMON GIBERELIN TERHADAP PERTUMBUHAN DAN HASIL TANAMAN OKRA (Abelmoschus esculentus L)
}

\author{
(The Effect Of Gibberellins Hormone Concentration On The Growth And Yield Of The Okra \\ Plant (Abelmoschus esculentus L)
}

\author{
Farida dan Nani Rohaeni \\ Program Studi Agroteknologi, Sekolah Tinggi Pertanian Kutai Timur \\ Jl. Soekarno-Hatta No. 1 Sangatta, Kutai Timur \\ Email : farida@stiperkutim.ac.id ; nanirohaeni@stiperkutim.ac.id
}

Article Submitted : $12-10-2018$

Article Accepted : 13-01-2018

\begin{abstract}
The effect of gibberellins hormone concentration on the growth and yield of okra. The aims of research are (1) to determinate the effects of growth and yield of okra plant with gibberellins hormon treatment, (2) to determine the best concentration of gibberellns hormone on the growth and yield of okra plants. This research obtained for three mounth on January to Aprl 2018. The research was conducted in Diponegoro Street, Village Sangatta Sub-distrct East Kutai. This research uses is Completely Randomized Design (CRD) of non factorial experiments each of four treatments and six replcates, are : $\mathrm{g}_{0}=$ without fertilizer, $\mathrm{g}_{1}=150 \mathrm{ppm}, \mathrm{g}_{2}=200 \mathrm{ppm}, \mathrm{g}_{3}=250$ ppm. The obtained data was analyzed by $\mathrm{F}$ test $1 \%$ and $5 \%$ and be continued with LSD at $5 \%$ if the treatment had significant effect. The results of the best growth research plant height 7 MST $(75,141 \mathrm{~cm})$ and growth of the leaves number $7 \mathrm{MST}$, best flowering age at 32,167 day and the best yield production result is 971,333 gram solid treatment.
\end{abstract}

Key words : okra, gibberellin hormone, concentration

\section{PENDAHULUAN}

Okra merupakan sayuran penting yang menduduki peringkat ketiga setelah bawang dan tomat (Afandi, 2016). Okra telah dikenal sebagai tanaman multiguna karena hampir semua bagian tanaman dapat dimanfaatkan (Idawati, 2016). Hasil penelitan ilmiah tentang kandungan senyawa dan khasiat okra sudah banyak dilakukan diberbagai negara. Departemen Pertanian Amerika Serikat menyebutkan okra rendah kalori, kaya nutrisi dan merupakan sumber serat yang baik (Trubus, 2016).

Okra merupakan sayuran berbentuk buah yang dapat diolah menjadi beragam makanan lezat dan berkhasiat bagi kesehatan. Buah okra mengandung banyak lendir sehingga rata-rata rakyat Indonesia menggunakan sebagai lauk pauk. Jepang sebagai negara yang suka dengan okra menggunakan buah okra sebagai cemilan dan bahan untuk membuat sushi (Dewi, 2009).

Okra mengandung kandungan gizi yang cukup tinggi dimana setiap 100 gram buah okra mengandung 1 gram lendir, 7 gram karbohidrat, dan 70-90 mg Ca. Dalam skala persen kandungan gizi buah okra adalah 3,9\% protein, 2,06\% lemak, 6,68\% kalium, 0,77 phospor dan $1,4 \%$ karbohidrat (Idawati, 2012).

Budidaya tanaman okra akan menghasilkan pertumbuhan yang baik nantinya akan mengarah pada produksi buah, bila kebutuhan tanaman okra terpenuhi tidak hanya kebutuhan unsur hara saja namun kebutuhan hormon khususnya hormon 
giberelin, dalam jumlah kecil juga dibutuhkan tanaman okra untuk meningkatkan pertumbuhan dan hasil buah okra (Yeni, 2012). Hormon giberelin merupakan hormon yang mempercepat perkecambahan biji, kuncup tunas, perpanjangan batang, pertumbuhan daun, merangsang pembungaan, dan mempengaruhi pertumbuhan deferensiasi akar (Campbell, 2005).

Berdasarkan penelitian Yeni (2012), menunjukkan bahwa dari perlakuan induksi giberelin $200 \mathrm{ppm}$ memberikan pertumbuhan dan produksi cabai merah yang paling tinggi yaitu 565 gram. Oleh karena itu perlu diteliti konsentrasi giberelin agar dapat menghasilkan pertumbuhan dan produksi tanaman okra yang optimal.

Tujuan dari penelitian ini adalah (1) untuk mengetahui pengaruh hormon giberelin terhadap pertumbuhan dan hasil tanaman okra, (2) untuk mengetahui konsentrasi hormon giberelin yang dapat menghasilkan pertumbuhan dan hasil tanaman okra yang terbaik.

\section{METODE PENELITIAN}

\section{Waktu dan Tempat}

Penelitian ini dilaksanakan pada bulan Januari sampai April 2018, dimulai dari persiapan lahan. Penelitian dilaksanakan di Jalan Diponegoro Desa Sangatta Utara Kabupaten Kutai Timur.

\section{Alat dan Bahan}

Alat yang digunakan dalam penelitian ini adalah cangkul, gembor kamera dan alat tulis. Sedangkan bahan yang digunakan dalam penelitian ini adalah benih okra,topsoil, polibag ukuran $40 \times 25 \mathrm{~cm}$, arang sekam, pasir, pupuk kandang giberelin.

\section{Rancangan Penelitian}

Penelitian ini menggunakan

Rancangan Acak Lengkap (RAL) non factorial yang terdiri dari terdiri atas 4 perlakuan dengan 6 ulangan. Taraf perlakuan yaitu $\mathrm{g}_{0}=$ tanpa giberelin, $\mathrm{g}_{1}=$ giberelin 150 ppm, $\mathrm{g}_{2}=$ giberelin $200 \mathrm{ppm}, \mathrm{g}_{3}=$ giberelin $250 \mathrm{ppm}$.

\section{Prosedur Penelitian}

1. Persiapan lahan

Lahan yang akan ditanami terlebih dahulu dibersihkan dari gulma. Kemudian siapkan topsoil, arang sekam, pasir dan pupuk kandang. Kemudian aduk semua media tanam tersebut sampai tercampur rata lalu masukkan ke dalam polibag ukuran $40 \mathrm{x}$ $25 \mathrm{~cm}$ dan didiamkan seminggu sebelum tanam.

\section{Penyemaian}

Benih okra direndam selama 4-6 jam. Benih yang digunakan adalah benih yang tenggelam saat perendaman (selain untuk seleksi benih, perendaman juga berfungsi untuk mempercepat perkecambahan). Lalu masukkan benih okra kedalam media tanam yang telah disiapkan. Kemudian tutup dengan tanah sedikit. Lalu tempatkan ditempat yang lembab. Setelah tanaman tinggi 8-10 $\mathrm{cm}$ dan berdaun 2-3 helai, maka tanaman siap dipindahkan ke dalam polibag.

\section{Penanaman}

Penanaman dilakukan dengan cara memindahkan benih dari media persemaian. Kemudian buat lubang tanam dengan kedalaman $10 \mathrm{~cm}$. Selanjutnya tepuk-tepuk sisi luar polibag tersebut dengan menggunakan telapak tangan agar media tanam tidak menempel di polibag. Setelah lepas dari polibag pegang tanaman pada bagian pangkal batang tanaman. Kemudian angkat tanaman secara perlahan-lahan sampai semua media terlepas dari polibag lalu segera dipindahkan ke dalam polibag yang baru. Polibag yang digunakan berukuran $40 \times 25 \mathrm{~cm}$ dengan jarak tanam masing-masing polibag $40 \mathrm{x} 40 \mathrm{~cm}$.

\section{Pemeliharaan}

Penyulaman dilakukan pada saat tanaman berumur 7 HST terhadap tanaman yang tidak tumbuh atau pertumbuhannya tidak normal (abnormal). Penyiraman dilakukan 2 kali sehari atau disesuaikan dengan kondisi curah hujan di lapangan. Penyiangan dilakukan dengan mencabut 
gulma yang tumbuh. Tujuan penyiangan untuk mencegah terjadinya kompetensi hara, sinar matahari, dan tempat tumbuhnya tanaman. Penyiangan dilakukan mulai 7 hari setelah tanam, selanjutnya dilakukan secara berkala setiap seminggu sekali sampai panen. 5. Pemberian hormon giberelin

Hormon giberelin diberikan saat tanaman berumur 15 HST sebanyak 30\% dan umur 35 HST sebanyak 70\% dari konsentrasi yang telah ditentukan sesuai perlakuan yaitu 150 ppm, 200 ppm, dan 250 ppm. Pemberian giberelin dilakukan dengan cara disemprotkan pada seluruh bagian tanaman. 6.Panen

Proses pemanenan dilakukan secara bertahap saat tanaman berusia 45 hst sampai 60 hst yang ditandai dengan munculnya buah yang memiliki ukuran 5-8 $\mathrm{cm}$ berwarna hijau muda.

\section{Parameter Pengamatan}

Parameter pengamatan adalah sebagai berikut :

a. Tinggi Tanaman $(\mathrm{cm})$

Tinggi tanaman diukur pada umur 3, 5, dan 7 MST. Pengukuran tinggi tanaman dengan mengukur tinggi tanaman mulai dari permukaan tanah sampai titik tumbuh. Tinggi tanaman diukur dengan menggunakan meteran.

b. Jumlah Daun (helai)

Menghitung jumlah daun pada umur 3, 5, dan 7 MST. Jumlah daun dihitung dengan menghitung jumlah daun yang telah terbentuk secara sempurna. c. Umur berbunga $80 \%$

Umur berbunga dihitung sejak penanaman hingga mulai muncul bunga pertama. Pengamatan dan perhitungan umur berbunga dilakukan pada setiap hari dari setiap tanaman sampel.

d. Berat buah per petak (gram)

Berat buah perpetak dilakukan dengan menghitung berat buah dari tiap petak yang diakumulasikan dari panen pertama sampai dengan panen kelima.

\section{Analisis Data}

Data yang terkumpul dari hasil penelitian dengan menggunakan tabel Sidik Ragam. Bila hasil sidik ragam menunjukkan hasil yang berbeda nyata ( $\mathrm{F}$ hitung $>\mathrm{F}$ tabel $5 \%$ ) atau berbeda sangat nyata (F hitung $>\mathrm{F}$ tabel 1\%), maka untuk membandingkan ratarata perlakuan tersebut dengan menggunakan uji lanjut Beda Nyata Terkecil ( BNT ) pada taraf 5\%.

\section{HASIL DAN PEMBAHASAN}

\section{Tinggi Tanaman (cm)}

Berdasarkan hasil sidik ragam konsentrasi hormon giberelin menunjukkan tidak berbeda nyata terhadap rata-rata tinggi tanaman okra umur 3 dan 5 MST, tetapi menunjukkan sangat berbeda nyata terhadap rata-rata tinggi tanaman okra umur 7 MST. Hasil penelitian pengaruh konsentrasi hormon giberelin terhadap tinggi tanaman okra umur 3, 5, dan 7 MST dapat dilihat pada Tabel 1.

Tabel 1. Pengaruh konsentrasi hormon giberelin terhadap tinggi tanaman okra umur 3, 5, dan 7 MST (cm)

\begin{tabular}{cccc}
\hline Perlakuan & 3 MST & 5 MST & 7 MST \\
\hline $\mathrm{G}_{0}$ & 16,181 & 36,556 & $60,367 \mathrm{a}$ \\
$\mathrm{G}_{1}$ & 17,167 & 38,889 & $73,400 \mathrm{~b}$ \\
$\mathrm{G}_{2}$ & 17,820 & 39,694 & $75,141 \mathrm{~b}$ \\
$\mathrm{G}_{3}$ & 17,153 & 40,556 & $77,000 \mathrm{~b}$ \\
\hline
\end{tabular}

Keterangan : Angka rata-rata yang diikuti oleh huruf yang sama berarti menunjukkan tidak berbeda nyata pada uji BNT taraf 5\% (BNT 7 MST $=8,314)$ 
Pengamatan tinggi tanaman okra umur 3 MST menunjukkan tidak terdapat pengaruh yang nyata. Hal ini diduga karena faktor genetik yang berasal dari tanaman sehingga tidak memberikan pengaruh terhadap tinggi tanaman umur 3 MST. Pernyataan tersebut sesuai dengan pendapat Gardner dalam Arifin (2011), faktor yang mempengaruhi pertumbuhan secara luas dapat dikategorikan sebagai faktor eksternal (lingkungan) dan faktor internal(genetik). Salah satu faktor internal yaitu pengaruh langsung gen, dimana dalam hal ini tinggi dari tanaman okra umur 3 MST.

Salisbury (1995), menyatakan bahwa setiap hormon mempengaruhi respon pada banyak bagian tumbuhan. Respon tersebut tergantung pada spesies, bagian tumbuhan, fase perkembangan, konsentrasi hormon, interaksi antar hormon dan faktor lingkungan. Gardner dalam Arifin (2011), juga menyatakan bahwa pertumbuhan dan perkembangan adalah proses yang berlangsung secara terus menerus sepanjang daur hidup, bergantung pada ketersediaan meristem, hasil asimilasi hormon dan substansi pertumbuhan lainnya serta lingkungan yang mendukung.

Perlakuan konsentrasi hormon giberelin tidak menunjukkan pengaruh yang nyata terhadap tinggi tanaman umur 5 MST. Hal ini diduga konsentrasi $30 \%$ yang diberikan pada tahap awal tidak mendukung pertumbuhan awal tanaman. Hal ini sesuai dengan pernyataan Gardner dalam Arifin (2011), bahwa penambahan hormon giberelin harus dengan konsentrasi yang tepat. Konsentrasi hormon giberelin yang tepat akan bekerja optimal dalam pertumbuhan tumbuhan. Selain itu menurut Mar'ah (2011), menyatakan bahwa rendahnya konsentrasi giberelin yang digunakan tidak memberikan pengaruh terhadap variable pengamatan tinggi tanaman. Salisbury dan Ross (1995), menyatakan zat pengatur tumbuh merupakan senyawa organik, bukan nutrisi dalam konsentrasi rendah dapat mendorong, menghambat atau secara kualitatif mengubah pertumbuhan dan perkembangan tanaman.

Perlakuan konsentrasi hormon giberelin memberikan pengaruh yang sangat nyata terhadap tinggi tanaman okra pada umur 7 MST. Pada konsentrasi yang diberikan menunjukkan kenaikan data ratarata tinggi tanaman bila dibandingkan dengan parameter tinggi tanaman sebelumnya. Kenaikan tersebut diduga karena telah berfungsinya hormon giberelin pada tanaman okra. Hal tersebut didasarkan oleh pendapat Zein (2007), bahwa gibereln memacu pertumbuhan sel. Mayeni (2007), juga menyatakan bahwa semakin tinggi konsentrasi yang diberikan maka semakin bertambah tinggi bibit kina. Ditambahkan oleh pendapat Dwidjosaputra (1997), giberelin menyebabkan tinggi tanaman 3 sampai 5 kali tinggi optimal. Kusuma (2009), menyatakan pembelahan sel distimulasi oleh aktifnya amilase menghidrolisis pati menjadi gula tereduksi sehingga konsentrasi gula meningkat akibat tekanan osmotik juga meningkat. Peningkatan tekanan osmotik di dalam sel menyebabkan air mudah masuk ke dalam sel sehingga dapat melakukan segala proses fisiologis dalam sel tanaman sehingga dapat memacu pertumbuhan sel yang menyebabkan pertumbuhan tinggi tanaman semakin baik. Dalam penelitan Yeni (2012), induksi giberelin 200 ppm memberikan pertumbuhan tanaman cabai yang paling baik.

Efek nyata giberelin terhadap tinggi tanaman berkaitan dengan fungsi giberelin dalam pemanjangan dan pembesaran sel. Giberelin mengontrol secara langsung pematangan pada sel tumbuhan dengan mengubah orientasi mikrofibril selulosa melalui perubahan orientasi kortikal dan juga mengubah asosiasi antara mikrotubul dengan membran plasma (Mayeni, 2007). Kelebihan giberelin dibandingkan dengan hormon lain yaitu giberelin mempunyai kemampuan khusus memacu pertumbuhan pada banyak spesies terutama tumbuhan kerdil atau tumbuhan dwi tahunan yang berada dalam 
fase roseta. Giberelin lebih banyak mendorong perpanjangan batang utuh (Zein, 2016). Ditambahkan oleh Dwijosaputra (1997), bahwa hormon giberelin menyebabkan tanaman yang kerdil menjadi tanaman raksasa dalam waktu singkat.

\section{Jumlah Daun (Helai)}

Berdasarkan hasil sidik ragam konsentrasi hormon giberelin menunjukkan tidak berbeda nyata terhadap rata-rata jumlah daun tanaman okra umur 3 dan 5 MST, tetapi menunjukkan berbeda nyata terhadap ratarata jumlah daun tanaman okra umur 7 MST. Hasil penelitian pengaruh konsentrasi hormon giberelin terhadap jumlah daun tanaman okra umur 3, 5, dan 7 MST dapat dilihat pada Tabel 2 di bawah ini.

Tabel 2. Pengaruh konsentrasi hormon giberelin terhadap jumlah daun tanaman okra umur 3, 5, dan 7 MST (cm)

\begin{tabular}{cccc}
\hline Perlakuan & 3 MST & 5 MST & 7 MST \\
\hline $\mathrm{G}_{0}$ & 7,444 & 16,222 & $36,556 \mathrm{a}$ \\
$\mathrm{G}_{1}$ & 7,424 & 16,472 & $38,889 \mathrm{~b}$ \\
$\mathrm{G}_{2}$ & 7,945 & 18,028 & $39,694 \mathrm{c}$ \\
$\mathrm{G}_{3}$ & 7,805 & 17,695 & $40,556 \mathrm{~d}$ \\
\hline
\end{tabular}

Keterangan : Angka rata-rata yang diikuti oleh huruf yang sama berarti menunjukkan tidak berbeda nyata pada uji BNT taraf 5\% (BNT 7 MST $=0,842)$

Aplikasi giberelin menunjukkan tidak berbeda nyata terhadap jumlah daun tanaman okra umur 3 dan 5 MST. Hal ini diduga karena aplikasi 30\% dari hormon giberelin pada tahap pertama, tidak mendukung pertumbuhan awal tanaman okra. Karena kurangnya unsur hara makro seperti nitrogen yang dibutuhkan untuk pembentukan daun. Sebagaimana pendapat Sutedjo (2007), bahwa kurangnya unsur hara makro seperti nitrogen yang dibutuhkan untuk mendukung pembentukan daun juga memberikan pengaruh terhadap rata-rata jumlah daun pada tanaman.

Aplikasi giberelin memberikan pengaruh yang nyata terhadap jumlah daun tanaman okra umur 7 MST. Hal ini diduga karena telah berfungsinya hormon giberelin yang telah diaplikasikan. Hal ini sesuai dengan pendapat Wattimena (2002), selain perpanjangan batang, giberelin juga memperbesar luas daun serta mempengaruhi pertumbuhan jumlah daun. Ditambahkan oleh Lakitan (2008) bahwa aplikasi hormon giberelin langsung ke daun akan merangsang pertumbuhan daun.

Menurut Salisbury dan Ross (1995), akar dan daun muda merupakan tempat utama produksi giberelin, sehingga giberelin dapat merangsang pertumbuhan pada daun, serta dapat memperbesar luas daun. Giberelin dapat memacu pertumbuhan tanaman dengan mempercepat proses pembelahan dan pertumbuhan sel. Aplikasi giberelin pada tanaman dengan konsentrasi yang lebih banyak akan meningkatkan pertumbuhan floem dan xylem. Hal ini yang menyebabkan pertumbuhan jumlah daun tanaman.

\section{Umur Berbunga 80\% (Hari)}

Berdasarkan hasil sidik ragam konsentrasi hormon giberelin menunjukkan sangat berbeda nyata terhadap rata-rata umur berbunga tanaman okra. Hasil penelitian pengaruh konsentrasi hormon giberelin terhadap rata-rata umur berbunga tanaman okra dapat dilihat pada Tabel 3 di bawah ini. 
Tabel 3. Pengaruh konsentrasi hormon giberelin terhadap rata-rata umur berbunga tanaman okra (hari)

\begin{tabular}{cc}
\hline Perlakuan & Umur Berbunga \\
\hline $\mathrm{G}_{0}$ & $35,667 \mathrm{~b}$ \\
$\mathrm{G}_{1}$ & $32,333 \mathrm{a}$ \\
$\mathrm{G}_{2}$ & $32,667 \mathrm{a}$ \\
$\mathrm{G}_{3}$ & $32,167 \mathrm{a}$ \\
\hline
\end{tabular}

Keterangan : Angka rata-rata yang diikuti oleh huruf yang sama berarti menunjukkan tidak berbeda nyata pada uji BNT taraf $5 \%(\mathrm{BNT}=1,827)$

Aplikasi hormon giberelin dengan konsentrasi 200 ppm dan 250 ppm memberikan waktu berbunga yang tercepat bila dibandingkan dengan perlakuan lainnya. Hal ini diduga karena perlakuan $\mathrm{G}_{2}(200$ ppm) dan $\mathrm{G}_{3} \quad(250 \mathrm{ppm})$ merupakan konsentrasi yang dibutuhkan bagi tanaman okra untuk berbunga lebih cepat. Sebagaimana pendapat Haryantini (2009), bahwa salah satu usaha agar terjadinya pembungaan yaitu dengan memberi zat pengatur tumbuh. Murni (2009), juga menjelaskan bahwa beberapa jenis zat pengatur tumbuh seperti hormon giberelin dapat mempengaruhi pembungaan. Ditambahkan pula oleh Dwidjosaputra (1997), bahwa gibereln dapat menyebabkan tanaman menghasilkan bunga sebelum waktunya.

Giberelin juga memenuhi kebutuhan beberapa spesies untuk menginduksi pembungaan agar berbunga lebih awal (Zein, 2016). Giberelin akan merangsang dan mempertinggi presentase timbulnya bunga karena giberelin dapat merangsang pembungaan serta dapat mengurangi gugurnya bunga dan buah sebelum waktunya (Heddy dalam Annisa, 2009). Dari sebuah hormon tanaman yang diaplikasikan hanya giberelin yang secara efektif mendorong pembentukan bunga (Arifin, 2011).

\section{Berat Buah Per Petak (Gram)}

Berdasarkan hasil sidik ragam konsentrasi hormon giberelin menunjukkan sangat berbeda nyata terhadap rata-rata berat buah per petak tanaman okra. Hasil penelitian pengaruh konsentrasi hormon giberelin terhadap rata-rata berat buah per petak tanaman okra dapat dilihat pada Tabel 4

Tabel 4. Pengaruh konsentrasi hormon giberelin terhadap rata-rata berat buah per petak tanaman okra (gram)

\begin{tabular}{cc}
\hline Perlakuan & Berat Buah Per Petak $(\mathrm{g})$ \\
\hline $\mathrm{G}_{0}$ & $653,500 \mathrm{a}$ \\
$\mathrm{G}_{1}$ & $791,833 \mathrm{~b}$ \\
$\mathrm{G}_{2}$ & $971,333 \mathrm{~d}$ \\
$\mathrm{G}_{3}$ & $870,833 \mathrm{c}$ \\
\hline
\end{tabular}

Keterangan : Angka rata-rata yang diikuti oleh huruf yang sama berarti menunjukkan tidak berbeda nyata pada uji BNT taraf 5\% $(\mathrm{BNT}=10,739$

Perlakuan $\quad \mathrm{G}_{2} \quad(200 \quad \mathrm{ppm})$ memperlihatkan hasil yan erbaik terhadap berat buah per petak yaitu 971,333 gram. Hal ini diduga karena perlakuan $\mathrm{G}_{2}$ mendapatkan aplikasi zat pengatur tumbuh berupa hormon giberelin dengan konsentrasi yang sesuai bagi tanaman okra, sehingga memberikan produksi yang optimal. Menurut Haryantini (2009), salah satu usaha untuk mengatasi pembentukan buah dan hasil yang tinggi 
yaitu dengan pemberian zat pengatur tumbuh. Pendapat tersebut didukung oleh Syafi'i (2006), yang menyatakan bahwa zat pengatur tumbuh merupakan salah satu alternative yang berguna untuk memacu pertumbuhan dan perkembangan tanaman sehingga tanaman bisa lebih cepat pertumbuhannya dan menghasilkan produksi yang lebih tinggi. Arifin (2011), menyatakan bahwa hormon giberelin akan merangsang presentase timbulnya buah. Pada fase produksi yaitu pada pembungaan dan pembuahan, giberelin akan merangsang serta mengurangi gugurnya buah sebelum waktunya (Yeni, 2012). Ditambahkan oleh Asra (2014), menyatakan bahwa aplikasi hormon giberelin akan mampu menginduksi sel sehingga ukuran buah menjadi lebih besar. Pemberian giberelin eksogen dapat efektif apabila diberikan sesuai dengan kebutuhan tanaman. Aplikasi giberelin dengan konsentrasi yang terlalu rendah dan konsentrasi yang lebih tinggi dapat menghambat produksi buah. Hormon giberelin akan bekerja optimal dengan konsentrasi yang tepat. Hormon giberelin dengan konsentrasi yang sesuai nantinya akan mengarah pada hasil produksi (Susanti, 2006).

Abidin (2002), menyatakan bila ketersediaan unsur hara cukup dan seimbang maka pembelahan sel akan tumbuh dan berkembang serta berproduksi secara maksimal. Berdasarkan penelitian Yeni (2012), menunjukkan pemberian giberelin 200 ppm meningkatkan produksi buah lebih tinggi dibandingkan dengan kontrol.

\section{KESIMPULAN}

Kesimpulan dari penelitian ini adalah : Perlakuan $\mathrm{G}_{2}$ (hormon giberelin dengan konsentrasi 200 ppm) menunjukkan pertumbuhan dan hasil yang terbaik pada tanaman okra, karena menghasilkan berat buah per petak yaitu 971,333 gram/petak.

\section{DAFTAR PUSTAKA}

Abidin, Z. 2002. Dasar - Dasar Pengetahuan Tentang Zat Pengatur Tumbuh. Angkasa. Bandung.

Afandi. 2016. Pengaruh Pemberian Dosis Pupuk Urea Pada Berbagai Galur Terhadap Pertumbuhan, Hasil dan Kualitas Okra. Program Studi Agroteknologi. Fakultas Pertanian Jember.

Arifin, Z. 2011. Pengaruh Konsentrasi GA3 Terhadap Pembungaan dan Kualitas Benih Cabai Merah Keriting. Fakutas Pertanian Universitas Gadjah Mada. Yogyakarta.

Asra, R. 2014. Pengaruh Hormon Giberelin Terhadap Daya Kecambah dan Vigoritas Calopogonium caeruleum. Fakultas Sains dan teknologi Fakultas Jambi. Jambi.

Annisa. 2009. Pengaruh Induksi Giberelin Terhadap Pembentukan Buah Partenokapri Pada Beberapa Varietas Tanaman Semangka. Skripsi. Fakultas Pertanian Universitas Sumatera Utara Medan.

Dewi, M. 2009. Respon Tanaman Okra Terhadap Beberapa Jenis Tanah dan Pupuk Amazing Bio Growth. Tesis Magister Pertanian Universitas Islam Riau. Tidak Diterbitkan.

Dwidjosaputra. 1997. Pengantar Fisiologi Tumbuhan. PT. Gramedia Pustaka Utama. Jakarta

Gardner. 2008. Fisiologi Tumbuhan. PT. Gramedia Utama. Jakarta

Heddy, S. 1996. Hormon Tumbuhan. PT. Raja Gravindo Persada. Jakarta 
Haryatini, B.A. 2009. Aplikasi Mikoriza, Pupuk Fosfat dan Zat Pengatur Tumbuh Pada Tanaman Cabai Merah Di Tanah Andisol. Agritek vol 17 no 6: 11341144

Idawati. 2012. Peluang Besar Budidaya Okra. Yogyakarta. Pustaka Baru Press.

Kusumo ，S. 2009. Zat Pengatur Tumbuh Tanaman. Yasaguna. Jakarta

Lakitan. 2008. Fisiologi Pertumbuhan dan Perkembangan Tanaman. PT Raja Gravindo Persada. Jakarta

Mar'ah. 2011. Pengaruh Giberelin dan Nitrogen Terhadap Pertumbuhan Planlet Nenas Kultivar Smooth cayenne Hasil Kultur Jaringan. IPB. Bogor.

Murni D. 2009. Respon Tanaman Okra Terhadap Beberapa Jenis Tanah dan Pupuk Amazing Biogrowth. Universitas Isla Riau. Pekan Baru

Mayeni, R. 2007. Pengaruh Beberapa Konsentrasi Giberelin TerhadapPertumbuhan Bibit Kina. Universitas Andalas. Padang
Syafi'i. 2006. Pengaruh Konsentrasi dan Waktu Pemberian Giberelin Terhadap Pertumbuhan dan Hasil Tanaman Melon Dengan Sistem Hidroponik irigasi Tetes. Fakultas Pertanian UNS. Solo

Salisburry FB dan CW Ross. 1995. Fislogi Tumbuhan Jilid 2. Penerjemah : Lukman DR dan Sumaryono. Penerbit ITB

Susanti, D. 2006. Studi Penggunaan Asam Giberelat Untuk Meningkatkan Kualitas Polong Tanaman Okra. Thesis Universitas Lampung

Sutedjo. 2007. Pupuk dan Pemupukan. Jakarta. Rineke Cipta

Yeni, T. 2012. Pengaruh Induksi Giberelin Terhadap Pertumbuhan dan Produksi Tanaman Cabai Merah. FKIP Universitas Muhammadiyah

Watimena, B. 2002. Bertanam Tomat. PT Agro Media Pustaka. Jakarta

Zein. 2016. Dasar-Dasar Fisiologi Tumbuhan. PT Gravindo Persada. Jakarta 